\title{
Chemistry of Heterometallic Phenyl Imido and Phosphinidene Clusters
}

\author{
Yun Chi, ${ }^{1,3}$ Ren-Chiun Lin, ${ }^{1}$ Shie-Ming Peng, ${ }^{2}$ and Gene-Hsiang Lee ${ }^{2}$
}

Received November 6, 1992

\begin{abstract}
Triruthenium imido cluster $\mathrm{Ru}_{3}(\mathrm{CO})_{10}\left(\mu_{3}-\mathrm{NPh}\right)^{(1)}$ reacts with tungsten hydride $L W(\mathrm{CO})_{3} \mathrm{H}$ to afford heterometallic imido clusters $\mathrm{LWRu}_{2}(\mathrm{CO})_{8}(\mu-\mathrm{H})$ $\left(\mu_{3}-\mathrm{NPh}\right), \mathbf{L}=\mathrm{Cp},(\mathbf{I} \mathbf{a}) ; \mathbf{L}=\mathrm{Cp}^{*},(\mathbf{I} \mathbf{b})$, whereas the respective phosphinidene complexes $\mathrm{LWRu}_{2}(\mathrm{CO})_{8}(\mu-\mathrm{H})\left(\mu_{3}-\mathrm{PPh}\right), \mathrm{L}=\mathrm{Cp},(\mathbf{I X a}) ; \mathrm{L}=\mathrm{Cp} *$, (IXb), wcre generated via reaction of $\mathrm{Ru}_{3}(\mathrm{CO})_{10}(\mu-\mathrm{H})\left(\mu-\mathrm{PPh}_{2}\right)$ with $\mathrm{CpW}(\mathrm{CO})_{3} \mathrm{H}$ and with $\mathrm{Cp} * \mathrm{~W}(\mathrm{CO})_{3} \mathrm{H}$ followed by thermolysis in the presence of carbon monoxide. Their molecular structure, solution dynamics, and the subsequent reaction with hexafluoro-2-butyne are presented.
\end{abstract}

KEY WORDS: Heterometallic cluster; ruthenium; tungsten; imido; phosphinidene.

\section{INTRODUCTION}

The chemistry of transition metal clusters possessing imido [1] and phosphinidene [2] ligands has been investigated extensively in recent years. We have been interested in the synthesis of heterometallic imido clusters $\mathrm{LWRu}_{2}(\mathrm{CO})_{8}(\mu-\mathrm{H})\left(\mu_{3}-\mathrm{NPh}\right), \mathrm{L}=\mathrm{Cp},(\mathbf{I I a}) ; \mathrm{L}=\mathrm{Cp}^{*}$, (IIb), via treatment of $\mathrm{Ru}_{3}(\mathrm{CO})_{10}\left(\mu_{3}-\mathrm{NPh}\right)$ with tungsten hydrides $\mathrm{LW}(\mathrm{CO})_{3} \mathrm{H}$ [3]. The corresponding phosphinidene complexes $\mathrm{LWRu}_{2}(\mathrm{CO})_{8}(\mu-\mathrm{H})\left(\mu_{3}-\mathrm{PPh}\right)$, $\mathrm{L}=\mathrm{Cp},(\mathbf{I X a}) ; \mathrm{L}=\mathrm{Cp}^{*}$, (IXb), were generated from phosphido complex $\mathrm{Ru}_{3}(\mathrm{CO})_{10}(\mu-\mathrm{H})\left(\mu-\mathrm{PPh}_{2}\right)$ and $\mathrm{LW}(\mathrm{CO})_{3} \mathrm{H}$ in refluxing toluene solution [4]. Here we summarize the synthesis and characterization of these heterometallic phenylimido and phosphinidene clusters. Attention

\footnotetext{
'Department of Chemistry, National Tsing Hua University, Hsinchu 30043, Taiwan, Republic of China.

${ }^{2}$ Department of Chemistry, National Taiwan University, Taipei 10764, Taiwan, Republic of China.

${ }^{3}$ To whom all correspondence should be addressed.
} 
is focused on the subsequent reactivity, such as reactions with hexafluoro-2-butyne. For the reaction of IIa, we isolated an alkenyl-imido complex $\mathrm{CpWRu}_{2}(\mathrm{CO})_{7}\left(\mu_{3}-\mathrm{NPh}\right)\left[\mathrm{C}\left(\mathrm{CF}_{3}\right) \mathrm{CH}\left(\mathrm{CF}_{3}\right)\right]$ (IIIa) in over $65 \%$ yield and a second cluster compound $\mathrm{CpWRu}_{2}(\mathrm{CO})_{5}(\mu-\mathrm{NPh})\left[\mathrm{C}_{2}\left(\mathrm{CF}_{3}\right)_{2}\right]$ $\left[\mathrm{C}\left(\mathrm{CF}_{3}\right) \mathrm{CH}\left(\mathrm{CF}_{3}\right)\right](\mathbf{I V})$ in a small quantity. The crystal structure of $\mathrm{IV}$ suggests that it is generated via sequential addition of two alkyne molecules but the reactivity indicates that its formation has not passed through the complex IIIa as an intermediate.

\section{EXPERIMENTAL PROCEDURE}

Infrared spectra were recorded on a Bomen M-100 FT-IR spectrometer. ${ }^{1} \mathrm{H},{ }^{13} \mathrm{C}$ and ${ }^{19} \mathrm{~F}$ NMR spectra were recorded on a Bruker $\mathrm{AM}-400(400 \mathrm{MHz})$ instrument. Mass spectra were obtained on a JEOL-HX110 instrument operating in fast-atom bombardment (FAB) mode. All reactions were performed under a dinitrogen atmosphere using deoxygenated solvents dried with an appropriate reagent. The progress of reactions was monitored by analytical thin-layer chromatography (5735 Kieselgel $60 \mathrm{~F}_{254}$, E. Merck) and the products were separated on commercially available preparative thin-layer chromatographic plates (Kieselgel 60 $F_{254}$, E. Merck). Elemental analyses were performed at the NSC Regional Instrumentation Center at National Cheng Kung University, Tainan, Taiwan.

\section{Reaction of IIa with Hexafluoro-2-butyne}

A toluene solution (15 ml) of $\mathrm{CpWRu}_{2}(\mathrm{CO})_{8}\left(\mu_{3}-\mathrm{NPh}\right)(\mu-\mathrm{H})^{(3)}$ (150 $\mathrm{mg}, 0.185 \mathrm{mmol}$ ) and excess of hexafluoro-2-butyne was placed in a $50 \mathrm{ml}$ sealed tube and heated at $100^{\circ} \mathrm{C}$ for 10 minutes. The color of solution gradually changed from orange to dark brown. After evaporation of the solvent in vacuo, the residue was separated by TLC (silica gel, dichloromethane:hexane $=1: 1$ ) and recrystallization, giving $104 \mathrm{mg}$ of $\mathrm{CpWRu}_{2}(\mathrm{CO})_{7}\left(\mu_{3}-\mathrm{NPh}\right)\left[\mathrm{C}\left(\mathrm{CF}_{3}\right) \mathrm{CH}\left(\mathrm{CF}_{3}\right)\right]($ IIIa, $0.116 \mathrm{mmol}, 60 \%)$ in addition to an orange-red complex $\mathrm{CpWRu}_{2}(\mathrm{CO})_{5}(\mu-\mathrm{NPh})\left[\mathrm{C}_{2}\left(\mathrm{CF}_{3}\right)_{2}\right]$ $\left[\mathrm{C}\left(\mathrm{CF}_{3}\right) \mathrm{CH}\left(\mathrm{CF}_{3}\right)\right](\mathrm{IV}, 14 \mathrm{mg}, 0.014 \mathrm{mmol}, 7.6 \%)$.

Spectral data for IV: MS (FAB, $\left.{ }^{102} \mathrm{Ru},{ }^{184} \mathrm{~W}\right), \mathrm{m} / \mathrm{z} 1009\left(\mathrm{M}^{+}\right)$. $\mathrm{IR}\left(\mathrm{CCl}_{4}\right): v(\mathrm{CO}), 2090(\mathrm{vs}), 2057(\mathrm{~s}), 2027(\mathrm{~m}), 2020(\mathrm{~s}), 2000(\mathrm{w}) \mathrm{cm}^{-1} ;{ }^{1} \mathrm{H}$ NMR $\left(400 \mathrm{MHz}, \mathrm{THF}-d_{8}, \mathrm{RT}\right): \delta 7.46\left(t, 2 \mathrm{H}, J_{\mathrm{H}-\mathrm{H}}=7.7 \mathrm{~Hz}\right), 7.25(t, 1 \mathrm{H}$, $\left.J_{\mathrm{H}-\mathrm{H}}=7.4 \mathrm{~Hz}\right), 6.74($ broad, $2 \mathrm{H}), 6.29(s, 5 \mathrm{H}), 2.95\left(q, 1 \mathrm{H}, J_{\mathrm{F}-\mathrm{H}}=8.0 \mathrm{~Hz}\right)$; ${ }^{19} \mathrm{~F}$ NMR $\left(282 \mathrm{MHz}\right.$, THF- $\left.d_{8}, \mathrm{RT}\right): \delta-41.77\left(q, 3 \mathrm{~F}, J_{\mathrm{F}-\mathrm{F}}=14.4 \mathrm{~Hz}\right)$, $-42.19\left(q, 3 \mathrm{~F}, J_{\mathrm{F}-\mathrm{F}}=10.2 \mathrm{~Hz}\right),-49.86\left(q, 3 \mathrm{~F}, J_{\mathrm{F}-\mathrm{F}}=14.4 \mathrm{~Hz}\right),-54.29$ $\left(m, 3 \mathrm{~F}, J_{\mathrm{F}-\mathrm{F}}=10.2 \mathrm{~Hz}, J_{\mathrm{F}-\mathrm{H}}=8.0 \mathrm{~Hz}\right) ;{ }^{13} \mathrm{C}$ NMR $\left(100 \mathrm{MHz}, \mathrm{THF}-d_{8}\right.$, 
$\mathrm{RT}): \mathrm{CO}, \delta 204.6,196.9,196.3,195.6,195.3 ; \delta 181.1\left(q, \mathrm{CCF}_{3}, J_{\mathrm{C}-\mathrm{F}}=\right.$ $35 \mathrm{~Hz}), 170.0\left(J_{\mathrm{W}-\mathrm{C}}=21 \mathrm{~Hz}, i-\mathrm{C}_{6} \mathrm{H}_{5}\right), 153.7\left(q, \mathrm{CCF}_{3}, J_{\mathrm{C}-\mathrm{F}}=40 \mathrm{~Hz}\right), 146.0$ $\left(q, \mathrm{CCF}_{3}, J_{\mathrm{C}-\mathrm{F}}=39 \mathrm{~Hz}\right), 133.7\left(q, \mathrm{CF}_{3}, J_{\mathrm{C}-\mathrm{F}}=274 \mathrm{~Hz}\right), 132.4\left(q, \mathrm{CF}_{3}\right.$, $\left.J_{\mathrm{C}-\mathrm{F}}=276 \mathrm{~Hz}\right), 131.4\left(0, m-\mathrm{C}_{6} \mathrm{H}_{5}\right), 131.3\left(q, \mathrm{CF}_{3}, J_{\mathrm{C}-\mathrm{F}}=276 \mathrm{~Hz}\right), 130.5(q$, $\left.\mathrm{CF}_{3}, J_{\mathrm{C}-\mathrm{F}}=275 \mathrm{~Hz}\right), 129.4\left(p-\mathrm{C}_{6} \mathrm{H}_{5}\right), 122.0\left(m, o-\mathrm{C}_{6} \mathrm{H}_{5}\right), 107.6\left(\mathrm{C}_{5} \mathrm{H}_{5}\right)$, $28.1\left(q, \mathrm{CHCF}_{3}, J_{\mathrm{C}-\mathrm{F}}=39 \mathrm{~Hz}\right)$. Anal. Calcd. for $\mathrm{C}_{24} \mathrm{H}_{11} \mathrm{~F}_{12} \mathrm{~N}_{1} \mathrm{O}_{5} \mathrm{Ru}_{2} \mathrm{~W}_{1}$ : C, 28.62; H, 1.10; N, 1.39. Found: C, 28.52; H, 1.16; N, 1.35.

\section{Reaction of IIIa with Hexafluoro-2-butyne}

A toluene solution $(15 \mathrm{ml})$ of IIIa $(20 \mathrm{mg}, 0.116 \mathrm{mmol})$ and excess of hexafluoro-2-butyne was placed in a $50-\mathrm{ml}$ sealed tube and heated at $120^{\circ} \mathrm{C}$ for 25 minutes. After evaporation of the solvent in vacuo, the residue was separated by TLC (silica gel, dichloromethane:hexane $=1: 1$ ), producing $8.5 \mathrm{mg}$ of IIIa $(0.116 \mathrm{mmol}, 43 \%)$ and approximate $0.8 \mathrm{mg}$ of IV $(0.014 \mathrm{mmol}, 2 \%)$.

\section{Reaction of IXb with Hexafluoro-2-butyne}

A toluene solution $(10 \mathrm{ml})$ of $\mathrm{Cp}^{*} \mathrm{WRu}_{2}(\mathrm{CO})_{8}(\mu-\mathrm{H})\left(\mu_{3}-\mathrm{PPh}\right),{ }^{4}(\mathbf{I X b}$, $85 \mathrm{mg}, 0.099 \mathrm{mmol})$ and excess of hexafluoro-2-butyne was placed in a $30-\mathrm{ml}$ sealed tube and heated at $100^{\circ} \mathrm{C}$ for 5 minutes. The color of the solution gradually changed from red to deep red. After evaporation of the solvent in vacuo, the residue was separated by TLC (silica gel, dichloromethane:hexane $=1: 1$ ) and recrystallization, giving $68 \mathrm{mg}$ of $\mathrm{Cp}^{*} \mathrm{WRu}_{2}(\mathrm{CO})_{8}\left(\left[\mu-\mathrm{P}(\mathrm{Ph}) \mathrm{C}\left(\mathrm{CF}_{3}\right) \mathrm{CH}\left(\mathrm{CF}_{3}\right)\right],(\mathbf{X}, 0.067 \mathrm{mmol}, 68 \%)\right.$ as red crystalline solid.

Spectral data for $\mathrm{X}$ : MS (FAB, $\left.{ }^{102} \mathrm{Ru},{ }^{184} \mathrm{~W}\right), m / z 1018\left(\mathrm{M}^{+}\right)$. $\mathrm{IR}\left(\mathrm{C}_{6} \mathrm{H}_{12}\right): \quad v(\mathrm{CO}), 2079(\mathrm{vs}), 2044(\mathrm{vs}), 2023(\mathrm{~s}), 2002(\mathrm{~m}), 1998(\mathrm{~m})$, 1955(w), 1938(vw), $1867(\mathrm{w}) \mathrm{cm}^{-1} ;{ }^{1} \mathrm{H}$ NMR $\left(400 \mathrm{MHz}, \mathrm{CDCL}_{3}, \mathrm{RT}\right): \delta$ $7.50-7.42(m, 5 \mathrm{H}), 2.73\left(q, J_{\mathrm{H}-\mathrm{F}}=9.0 \mathrm{~Hz}\right), 1.84(s, 15 \mathrm{H}) ;{ }^{19} \mathrm{~F} \quad \mathrm{NMR}$ $\left(282 \mathrm{MHz}, \mathrm{CDCl}_{3}, \mathrm{RT}\right): \delta-44.64\left(3 \mathrm{~F}, J_{\mathrm{F}-\mathrm{F}}=14.5 \mathrm{~Hz}, J_{\mathrm{F}-\mathrm{P}}=3 \mathrm{~Hz}\right)$, $-53.16\left(3 \mathrm{~F}, \quad J_{\mathrm{F}-\mathrm{F}}=14.5 \mathrm{~Hz}, \quad J_{\mathrm{F}-\mathrm{H}}=8.7 \mathrm{~Hz}, \quad J_{\mathrm{F}-\mathrm{P}}=1.7 \mathrm{~Hz}\right) ;{ }^{13} \mathrm{C} \quad \mathrm{NMR}$ $\left(100 \mathrm{MHz}, \mathrm{CDCl}_{3}, \mathrm{RT}\right): \mathrm{CO}, \delta 218.8\left(d, J_{\mathrm{P}_{-\mathrm{C}}}=12 \mathrm{~Hz}\right), 215.6\left(d, J_{\mathrm{P}_{-\mathrm{C}}}=\right.$ $3.1 \mathrm{~Hz}), 201.3,200.5,199.2(2 \mathrm{C}), 194.4\left(d, J_{\mathrm{P}-\mathrm{C}}=5 \mathrm{~Hz}\right) ; \delta: 140.3\left(d, i-\mathrm{C}_{6} \mathrm{H}_{5}\right.$, $\left.J_{\mathrm{P}-\mathrm{C}}=7 \mathrm{~Hz}\right) ;{ }^{31} \mathrm{P}$ NMR $\left(161 \mathrm{MHz}, \mathrm{CDCl}_{3}, \mathrm{RT}\right): \delta 106.5\left(J_{\mathrm{W}-\mathrm{P}}=257 \mathrm{~Hz}\right)$. Anal. Calcd. for $\mathrm{C}_{28} \mathrm{H}_{21} \mathrm{O}_{8} \mathrm{~F}_{6} \mathrm{PRu}_{2} \mathrm{~W}$ : C, 33.09; $\mathrm{H}, 2.08$. Found: $\mathrm{C}, 32.83$; H, 2.02.

\section{X-Ray Crystallography}

A red-orange crystal of $\mathbf{I V}$ with dimensions $0.10 \times 0.25 \times 0.40 \mathrm{~mm}^{3}$ was selected for X-ray analysis. The measurement was carried out on a Nonius 
Table I. Experimental Data of the X-Ray Diffraction Studies for IV

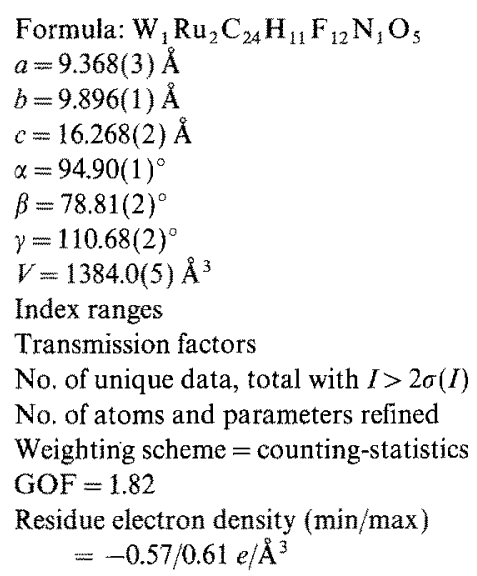

Mol. wt. 1007.33

Triclinic, space group $\mathrm{P} \overline{1}$

$Z=2$

$\lambda=0.70930 \AA$

$F(000)=944$

$D_{\text {calc }}=2.417 \mathrm{Mg} / \mathrm{m}^{3}$

$2 \theta(\max )=45^{\circ}$

$\mu=5.41 \mathrm{~mm}^{-1}$

$-10 \leqslant h \leqslant 9,0 \leqslant k \leqslant 10,-17 \leqslant l \leqslant 17$

$0.526 / 1.000$

3608,3284

56,407

$R_{F}, R_{W}=0.018,0.016$

Max. $\Delta / \sigma$ ratio $=0.032$

CAD-4 diffractometer using graphite-monochromated $\mathrm{Mo}-\mathrm{K}_{\alpha}$ radiation. Cell parameters were obtained from 25 reflections with $2 \theta$ angle in the range 20.22-23.08 degrees. The 3284 unique reflections with $I>2.0 \sigma(I)$ were corrected for absorption, Lorentz and polarization effects. Scattering factors were taken from the International Tables for X-ray crystallography (1974). All data deduction and structural refinement were performed using the NRCC-SDP-VAX packages. The structures were solved by the direct method and refined by least-squares recycle. All the non-hydrogen atoms were refined with anisotropic temperature factors. The positions of all hydrogen atoms were calculated by assuming idealized geometries; their contributions were added to the structural factor calculations, but their positions were not refined. The data collection, refinement parameters, and results of analyses are given in Table I, whereas the atomic positional parameters are given in Table II.

\section{RESULTS AND DISCUSSION}

\section{Synthesis of $\mathrm{WRu}_{2}$ Imido Clusters}

Treatment of the triruthenium imido complex $\mathrm{Ru}_{3}(\mathrm{CO})_{10}\left(\mu_{3}-\mathrm{NPh}\right)(\mathbf{I})$ [5] with tungsten hydrides $\mathrm{LW}(\mathrm{CO})_{3} \mathrm{H}$ in refluxing toluene $\left(110^{\circ} \mathrm{C}\right.$, $20 \mathrm{~min}$ ) produced imido clusters, $\mathrm{LWRu}_{2}(\mathrm{CO})_{8}(\mu-\mathrm{H})\left(\mu_{3}-\mathrm{NPh}\right) \quad$ (IIa, $\left.\mathrm{L}=\mathrm{Cp}, 56 \% ; \mathrm{Ib}, \mathrm{L}=\mathrm{Cp}^{*}, 51 \%\right)$ in addition to trace proportions of $\mathrm{Ru}_{3}(\mathrm{CO})_{12}$ (Scheme 1) [3]. In complexes IIa and IIb the imido ligand 
Table II. Atomic Coordinates and Equivalent Isotropic Displacement Coefficients for IV

\begin{tabular}{|c|c|c|c|c|}
\hline & $x$ & $y$ & $z$ & Biso \\
\hline W & $0.863028(23)$ & $0.190396(22)$ & $0.326441(12)$ & $2.169(9)$ \\
\hline Rul & $1.14336(4)$ & $0.39132(4)$ & $0.273763(23)$ & $2.327(18)$ \\
\hline Ru2 & $0.99475(5)$ & $0.26096(4)$ & $0.143464(23)$ & $2.437(20)$ \\
\hline $\mathrm{N}$ & $0.8085(4)$ & $0.1065(4)$ & $0.22979(21)$ & $2.25(19)$ \\
\hline $\mathrm{Cl}$ & $1.3279(6)$ & $0.3839(5)$ & $0.2011(3)$ & $3.6(3)$ \\
\hline $\mathrm{C} 2$ & $1.2563(6)$ & $0.5880(5)$ & $0.3048(3)$ & $3.5(3)$ \\
\hline $\mathrm{C} 3$ & $1.1561(6)$ & $0.3834(6)$ & $0.0693(3)$ & $3.8(3)$ \\
\hline $\mathrm{C} 4$ & $0.8516(6)$ & $0.2434(5)$ & $0.0698(3)$ & $3.6(3)$ \\
\hline $\mathrm{C} 5$ & $1.0666(6)$ & $0.1000(6)$ & $0.0973(3)$ & $3.6(3)$ \\
\hline C6 & $1.1386(6)$ & $0.0663(5)$ & $0.3028(3)$ & $3.5(3)$ \\
\hline $\mathrm{C} 7$ & $1.0872(5)$ & $0.1920(5)$ & $0.3320(3)$ & $2.53(25)$ \\
\hline $\mathrm{C} 8$ & $1.1653(5)$ & $0.3033(5)$ & $0.3859(3)$ & $3.0(3)$ \\
\hline $\mathrm{C} 9$ & $1.3208(6)$ & $0.3309(6)$ & $0.4071(3)$ & $3.8(3)$ \\
\hline $\mathrm{C} 10$ & $0.9807(6)$ & $0.5746(5)$ & $0.1783(3)$ & $3.8(3)$ \\
\hline $\mathrm{C} 11$ & $0.9710(5)$ & $0.4373(5)$ & $0.2168(3)$ & $2.53(24)$ \\
\hline $\mathrm{C} 12$ & $0.9110(5)$ & $0.4072(5)$ & $0.3034(3)$ & $2.34(23)$ \\
\hline $\mathrm{C} 13$ & $0.8749(6)$ & $0.5166(6)$ & $0.3662(3)$ & $3.8(3)$ \\
\hline $\mathrm{C} 14$ & $0.6965(5)$ & $-0.0082(5)$ & $0.1920(3)$ & $2.59(25)$ \\
\hline $\mathrm{C} 15$ & $0.5698(5)$ & $0.0155(5)$ & $0.1718(3)$ & $3.4(3)$ \\
\hline $\mathrm{C} 16$ & $0.4674(6)$ & $-0.0921(6)$ & $0.1316(4)$ & $4.6(3)$ \\
\hline $\mathrm{C} 17$ & $0.4897(6)$ & $-0.2206(6)$ & $0.1106(3)$ & $4.9(3)$ \\
\hline $\mathrm{C} 18$ & $0.6135(6)$ & $-0.2461(6)$ & $0.1328(3)$ & $4.5(3)$ \\
\hline $\mathrm{C} 19$ & $0.7172(5)$ & $-0.1393(5)$ & $0.1734(3)$ & $3.4(3)$ \\
\hline $\mathrm{C} 20$ & $0.6596(6)$ & $0.1966(6)$ & $0.4366(3)$ & $3.9(3)$ \\
\hline $\mathrm{C} 21$ & $0.5999(6)$ & $0.0729(6)$ & $0.3893(3)$ & $4.1(3)$ \\
\hline $\mathrm{C} 22$ & $0.6802(6)$ & $-0.0211(6)$ & $0.3941(3)$ & $4.1(3)$ \\
\hline $\mathrm{C} 23$ & $0.7907(6)$ & $0.0477(6)$ & $0.4452(3)$ & $4.4(3)$ \\
\hline $\mathrm{C} 24$ & $0.7769(6)$ & $0.1806(6)$ & $0.4723(3)$ & $4.1(3)$ \\
\hline $\mathrm{O} 1$ & $1.4364(4)$ & $0.3791(4)$ & $0.15788(24)$ & $5.78(25)$ \\
\hline $\mathrm{O} 2$ & $1.3249(4)$ & $0.7006(4)$ & $0.32622(24)$ & $5.54(22)$ \\
\hline $\mathrm{O} 3$ & $1.2572(4)$ & $0.4545(4)$ & $0.02229(21)$ & $5.47(22)$ \\
\hline 04 & $0.7693(4)$ & $0.2397(4)$ & $0.02628(22)$ & $5.68(24)$ \\
\hline O5 & $1.1124(5)$ & $0.0125(4)$ & $0.06939(24)$ & $6.4(3)$ \\
\hline $\mathbf{F} 1$ & $1.0326(4)$ & $-0.0394(3)$ & $0.26751(21)$ & $5.55(20)$ \\
\hline $\mathrm{F} 2$ & $1.2670(4)$ & $0.0943(4)$ & $0.24526(22)$ & $6.48(21)$ \\
\hline F3 & $1.1635(4)$ & $0.0056(4)$ & $0.36566(20)$ & $6.86(24)$ \\
\hline $\mathrm{F} 4$ & $1.3147(4)$ & $0.2528(4)$ & $0.47107(20)$ & $6.43(21)$ \\
\hline F5 & $1.4220(3)$ & $0.3019(4)$ & $0.34445(19)$ & $5.72(21)$ \\
\hline F6 & $1.3879(3)$ & $0.4688(3)$ & $0.42986(19)$ & $5.36(18)$ \\
\hline F7 & $1.1016(4)$ & $0.6902(3)$ & $0.18960(21)$ & $5.83(20)$ \\
\hline $\mathrm{F} 8$ & $0.8542(4)$ & $0.6098(3)$ & $0.20634(21)$ & $6.01(20)$ \\
\hline F9 & $0.9878(4)$ & $0.5620(3)$ & $0.09485(19)$ & $6.43(23)$ \\
\hline F10 & $0.9678(3)$ & $0.6545(3)$ & $0.35285(19)$ & $5.01(18)$ \\
\hline F11 & $0.7289(3)$ & $0.5151(3)$ & $0.37200(19)$ & $4.86(18)$ \\
\hline $\mathrm{F} 12$ & $0.8861(3)$ & $0.4908(3)$ & $0.44467(17)$ & $4.73(18)$ \\
\hline
\end{tabular}


adopts a triply bridging mode and the hydride is associated with the unique $\mathrm{Ru}-\mathrm{Ru}$ edge. The mechanism is best understood as a metalexchange reaction [6], in which the reactions proceed by the replacement of $\mathrm{Ru}(\mathrm{CO})_{4}$ unit by an isoelectronic $\mathrm{LW}(\mathrm{CO})_{2} \mathrm{H}$ fragment; the co-product $\mathrm{Ru}_{3}(\mathrm{CO})_{12}$ is generated by the trimerization of the departing $\mathrm{Ru}(\mathrm{CO})_{4}$ unit. In conformity with this reaction mechanism, Geoffroy et al. have reported the preparation of the heteronuclear cluster compound $\mathrm{HCoRu}_{2}(\mathrm{CO})_{9}\left(\mu_{3}-\mathrm{NPh}\right)$ via addition of cobalt carbonyl anion $\left[\mathrm{Co}(\mathrm{CO})_{4}\right]^{-}$to $\mathbf{I}$, followed by protonation with $\mathrm{HBF}_{4}[7]$.

\section{Reactions of Imido Clusters with Hexafluoro-2-butyne}

In contrast to the reactions between the parent phenylimido cluster I and disubstituted alkynes which yield the metallapyrrolinone complexes, the corresponding alkyne addition reactions with clusters IIa and IIb suffer from sample decomposition. However, the respective reactions with the electron-withdrawing alkyne are different: treatment of the imido cluster IIa with an excess of hexafluoro-2-butyne in a sealed-tube $\left(100^{\circ} \mathrm{C}\right.$, $10 \mathrm{~min})$ afforded a dark-green insertion product $\mathrm{CpWRu}_{2}(\mathrm{CO})_{7}\left(\mu_{3}-\mathrm{NPh}\right)$ $\left(\mathrm{CF}_{3} \mathrm{CCHCF}_{3}\right)$ (IIIa) in $60 \%$ yield and an orange-red, double addition product $\mathrm{CpWRu}_{2}(\mathrm{CO})_{5}(\mu-\mathrm{NPh})\left[\mathrm{C}_{2}\left(\mathrm{CF}_{3}\right)_{2}\right]\left[\mathrm{C}\left(\mathrm{CF}_{3}\right) \mathrm{CH}\left(\mathrm{CF}_{3}\right)\right]$ (IV) in $8 \%$ yield, whereas the respective reaction with the $\mathrm{Cp} *$ derivative Illb gave the alkenyl cluster (IIIb) in nearly $90 \%$ yield (Scheme 1) [8]. No doubleaddition product was observed for the reaction with $\mathrm{Cp}^{*}$ derivative IIb.
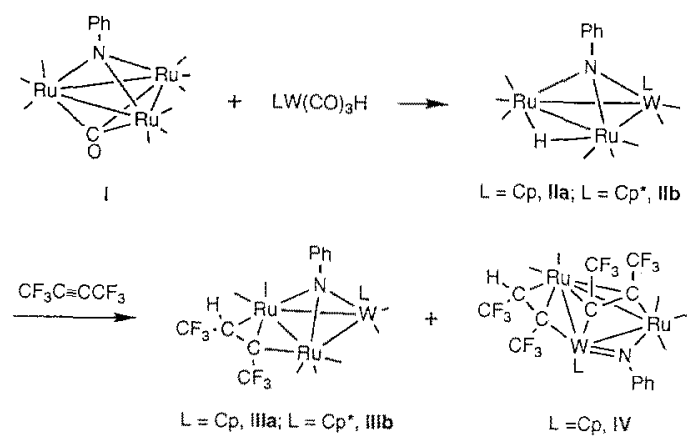

Scheme 1

\section{Characterization of III and Structural Determination of IV}

Complexes IIIa and IIIb possess an isosceles $\mathrm{WRu}_{2}$ cluster core, a face-bridging imido ligand and an edge-bridging cis-alkenyl ligand. The 


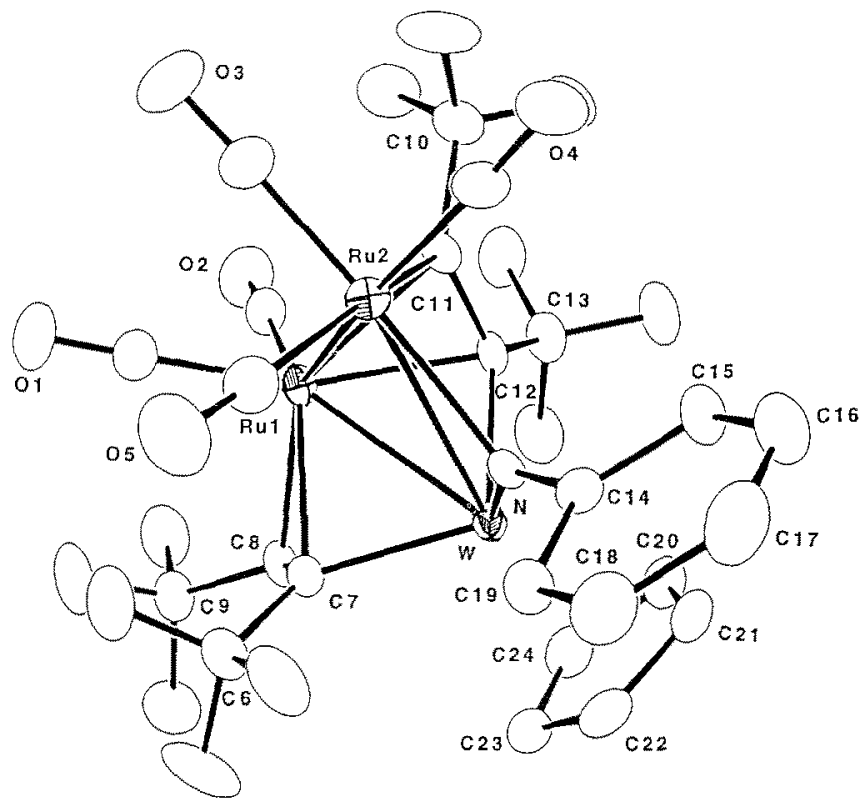

Fig. 1. Molecular structure of IV. Bond lengths $(\AA)$ : $W-R u(1)=2.7047(10)$, $W-R u(2)=$ $3.0319(7), \quad \operatorname{Ru}(1)-\mathrm{Ru}(2)=2.7395(8), \quad \mathrm{W}-\mathrm{N}=1.792(4), \quad \mathrm{Ru}(2)-\mathrm{N}=2.211(3), \quad \mathrm{W}-\mathrm{C}(7)=$ $2.114(4), \mathrm{Ru}(1)-\mathrm{C}(7)=2.111(4), \mathrm{C}(7)-\mathrm{C}(8)=1.424(7), \mathrm{Ru}(1)-\mathrm{C}(8)=2.161(4), \mathrm{W}-\mathrm{C}(12)=$ 2.082(4), $\quad \operatorname{Ru}(2)-\mathrm{C}(11)=2.082(5), \quad \mathrm{Ru}(1)-\mathrm{C}(11)=2.201(4), \quad \mathrm{Ru}(1)-\mathrm{C}(12)=2.195(4)$, C(11) $\mathrm{C}(12)=1.426(6)$.

mode of the imido ligand is analogous to the homometallic analogues $\mathrm{Ru}_{3}(\mathrm{CO})_{10}\left(\mu_{3}-\mathrm{NPh}\right), \quad \mathrm{H}_{2} \mathrm{Ru}_{3}(\mathrm{CO})_{9}\left(\mu_{3}-\mathrm{NPh}\right)$ and $\mathrm{Ru}_{3}(\mathrm{CO})_{8}(\mathrm{DPPM})$ $\left(\mu_{3}-\mathrm{NPh}\right)[9]$, whereas the alkenyl ligand resembles that of the regular edge-bridging alkenyl ligand observed in several group 8 dinuclear [10] and trinuclear alkenyl complexes [11].

For complex IV, a single-crystal X-ray diffraction study has been carried out. A view of the molecular structure is presented in Fig. 1 along with the selected parameters of bond lengths and angles. The cluster core consists of an isosceles $\mathrm{W}_{2} \mathrm{Ru}$ arrangement with $\mathrm{W}-\mathrm{Ru}(1)=2.7047(10)$, $\mathrm{Ru}(1)-\mathrm{Ru}(2)=2.7395(8)$, and $\mathrm{W}-\mathrm{Ru}(2)=3.0319(7) \AA$. The imido ligand bridges the $\mathrm{W}-\mathrm{Ru}(2)$ edge with $\mathrm{W}-\mathrm{N}=1.792(4)$ and $\mathrm{Ru}(2)-\mathrm{N}=$ 2.211 (3) $\AA$, while the cis- $\mathrm{C}\left(\mathrm{CF}_{3}\right)=\mathrm{CH}\left(\mathrm{CF}_{3}\right)$ group lies on the $\mathrm{W}-\mathrm{Ru}(1)$ edge and the hexafluoro-2-butyne fragment adopts the typical $\mu_{3}-\eta^{2}$-mode [12]. Although complex IV might be considered a derivative of IIIa, generated via addition of one additional hexafluoro-2-butyne and elimination of two CO molecules, this hypothesis is excluded because the direct reaction of IIIa with diphenylacetylene yields no stable cluster molecule 
and with hexafluoro-2-butyne affords only trace IV ( $\leqslant 2 \%)$ under identical conditions. Thus, the formation of IV does not involve complex IIIa as intermediate but proceeds via the simultaneous addition of two hexafluro-2-butyne molecules to imido cluster IIa, in which one hexafluoro-2-butyne fragment remains the same but the second one couples with the bridging hydride to give the observed alkenyl fragment. No attempt was made to verify the proposed mechanism.

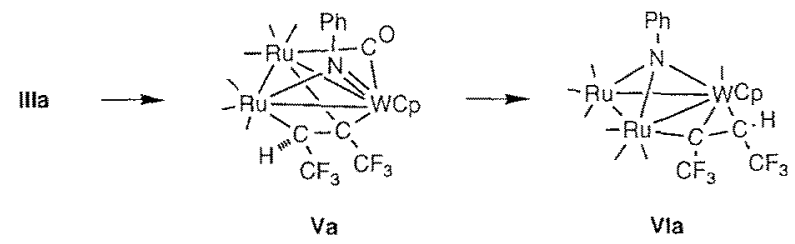

Scheme 2

\section{Alkenyl Rearrangement on the $\mathrm{WRu}_{2}$ Metal Triangle}

Complex IIIa underwent an unprecedented imido-ligand-assisted alkenyl migration. Thermolysis of IIIa under $\mathrm{CO}$ in toluene $\left(1 \mathrm{~atm}, 110^{\circ} \mathrm{C}\right.$, 1.5 hour) afforded two isomeric derivatives Va (amber, 40\%) and VIa (orange, $36 \%$ ) in addition to some unreacted precursor (15\%). Extending the reaction period to $4 \mathrm{hr}$, we isolated VIa as major cluster product in approximate $82 \%$ yield. This result indicates that isomer $\mathbf{V a}$ is best considered an intermediate in the alkenyl rearrangement and that the isomers IIIa and VIa are the kinetic and the thermodynamic products, respectively (Scheme 2) [8]. X-ray structural analysis of Va indicates that this molecule possesses an edge-bridging $\mathrm{W}=\mathrm{N}(\mathrm{Ph}) \rightarrow \mathrm{Ru}$ imido ligand and a facebridging alkenyl groups. The derivative VIa is related to its presursor IIIa, possessing a face-bridging imido ligand and an edge-bridging alkenyl ligand associated with a $\mathrm{W}-\mathrm{Ru}$ edge instead of a $\mathrm{Ru}-\mathrm{Ru}$ edge. Consistent with this assignment the ${ }^{13} \mathrm{C}$ NMR spectrum of VIa shows one $\mathrm{W}-\mathrm{CO}$ signal at $\delta 230.6\left(J_{\mathrm{w}-\mathrm{C}}=160 \mathrm{~Hz}\right)$ and six $\mathrm{Ru}-\mathrm{CO}$ signals in the range $\delta$ 199.2-186.1. The structure of its phosphine derivative, generated via simple substitution and ortho-metallation, lends strong support to this postulate [8]. Based on the structural studies of IIIa, Va, and VIa and the chemical reactions, it is obvious that the cis-alkenyl group undergies migration from the unique $\mathrm{Ru}-\mathrm{Ru}$ edge to a $\mathrm{Ru}-\mathrm{W}$ edge through the face-bridging alkenyl fragment. The imido ligand moves simultaneously from face-bridging to edge-bridging and finally back to the face-bridging position to balance the electron distribution. This ligand movement differs greatly from the typical 
$\sigma \rightarrow \pi, \pi \rightarrow \sigma$ rearrangement (vinyl group flipping) observed for the edge-bridging alkenyl ligand [13].

Furthermore, the application of a $\mathrm{CO}$ atmosphere is essential to prevent unwanted cluster degradation, because if the reaction is carried out under nitrogen we observed substantial sample decomposition within 20 minutes. In contrast to IIIa, the respective $\mathrm{Cp}^{*}$ derivative IIIb is essentially inert under $\mathrm{CO}$ atmosphere but reacts by elimination of one $\mathrm{CO}$ molecule to afford a hydrido-alkyne complex $\mathrm{Cp} * \mathrm{WRu}_{2}(\mathrm{CO})_{6} \mathrm{H}(\mu-\mathrm{NPh})$ $\left[\mathrm{C}_{2}\left(\mathrm{CF}_{3}\right)_{2}\right]$ (VIIb) under nitrogen atmosphere (Scheme 3 ). This process is irreversible as complex VIIb failed to regenerate IIIb upon treatment with $\mathrm{CO}$ but afforded a different alkenyl derivative $\mathrm{Cp}^{*} \mathrm{WRu}_{2}(\mathrm{CO})_{7}(\mu-\mathrm{NPh})$ $\left(\mathrm{CCF}_{3} \mathrm{CHCF}_{3}\right)(\mathbf{V b})$ in $51 \%$ yield. The latter reaction is reversible since thermolysis of $\mathbf{V b}$ in the absence of $\mathrm{CO}$ regenerated VIIb in $56 \%$ yield. In general, these reactions complement those of the analogous $\mathrm{Cp}$ derivatives since thermolysis of IIIa failed to afford VIIa and thermolysis of $\mathbf{V b}$ under CO gave no indication of formation of the hypothetical VIb. The divergence in reactivity is probably due to the electron-releasing property of the $\mathrm{Cp}^{*}$ ligand [14]. Since the $\mathrm{Cp}^{*}$ ligand is a better electron-releasing group than $\mathrm{Cp}$, its presence can further stabilize the $\mathrm{W}=\mathrm{N}$ interaction in $\mathbf{V b}$ and $\mathbf{V I I} \mathbf{b}$, and therefore retards the regeneration of the $\mu_{3}$-imido mode and prohibits the formation of VIb. In VIIb, there is a signal at $\delta-5.83$ $\left(J_{\mathrm{W}-\mathrm{H}}=122 \mathrm{~Hz}\right)$ in the ${ }^{1} \mathrm{H}$ NMR spectra and the ${ }^{13} \mathrm{C}$ NMR spectrum shows a peak at $\delta 163.2$ with $J_{\mathrm{C}-\mathrm{W}}=21 \mathrm{~Hz}$ due to the ipso-carbon of phenylimido group, suggesting the existence of a W-bound terminal hydride and an edge-bridging imido group. These features were confirmed by single-crystal $\mathrm{X}$-ray diffraction analysis.

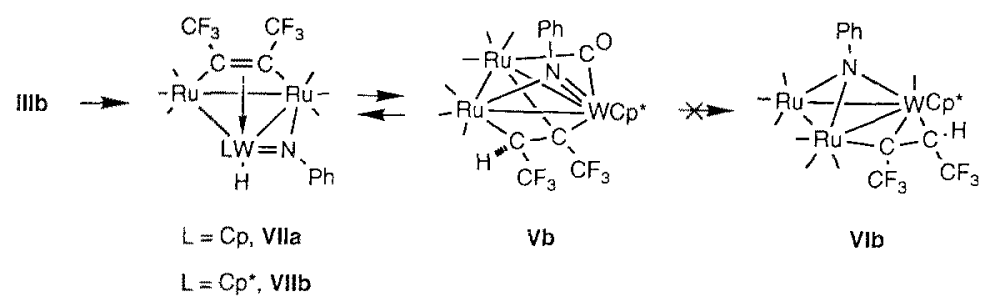

Scheme 3

\section{Synthesis of $\mathrm{WRu}_{2}$ Phosphinidene Clusters}

The synthesis of the $W_{R u_{2}}$ phosphinidene complexes is less straightforward because the phosphinidene analogue of $\mathbf{I}$ has yet been synthesized. However, we circumvented this difficulty by using diphenylphosphido clusters as precursors, as many phosphinidene cluster 
complexes were generated from the reaction with diphenylphosphine [15] and thermolysis of diphenylphosphido cluster via elimination of a benzene molecule [16]. In one paper, Carty and co-workers described preparation of the heterometallic cluster $\mathrm{Cp}_{2} \mathrm{Ni}_{2} \mathrm{Ru}_{3}(\mathrm{CO})_{9}\left(\mu_{5}\right.$ - $\left.\mathrm{PPh}\right)$ [17] via condensation of $\mathrm{Ru}_{3}(\mathrm{CO})_{9}(\mu-\mathrm{H})\left(\mu-\mathrm{PPh}_{2}\right)$ with $[\mathrm{CpNi}(\mathrm{CO})]_{2}$. Their discovery provides a hint that heterometallic phosphinidene clusters can be prepared from phosphido clusters as well [18]. Thus, we examined the reaction of the related $\mathrm{Ru}_{3}(\mathrm{CO})_{10}(\mu-\mathrm{H})\left(\mu-\mathrm{PPh}_{2}\right)$ with tungsten hydride $\mathrm{LW}(\mathrm{CO})_{3} \mathrm{H}$ because the former is known to undergo $\mathrm{CO}$ elimination to afford unsaturated $\mathrm{Ru}_{3}(\mathrm{CO})_{9}(\mu-\mathrm{H})\left(\mu-\mathrm{PPh}_{2}\right)[19]$.

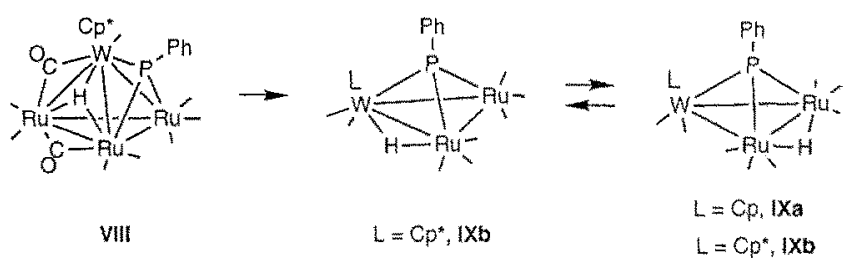

Scheme 4

Treatment of the triruthenium phosphido complex $\mathrm{Ru}_{3}(\mathrm{CO})_{10}$ $(\mu-\mathrm{H})\left(\mu-\mathrm{PPh}_{2}\right)$ with excess of $\mathrm{Cp} * \mathrm{~W}(\mathrm{CO})_{3} \mathrm{H}$ in refluxing toluene $(20 \mathrm{~min})$ produced a tetranuclear phosphinidene complex $\mathrm{Cp}^{*} \mathrm{WRu}_{3}(\mathrm{CO})_{10}$ $\left(\mu_{3}-\mathrm{H}\right)\left(\mu_{3}-\mathrm{PPh}\right)(\mathrm{VIIIa})$ in $45 \%$ yield (Scheme 4$)$. The basic structure is considered a $\mathrm{WRu}_{3} \mathrm{P}$ trigonal-bipyramidal arrangement or a distorted $\mathrm{WRu}_{3}$ tetrahedron capped by a phosphinidene ligand; two bridging $\mathrm{CO}$ ligands share a common $R u$ vertex and a face-bridging hydride ligand is located on a $\mathrm{WRu}_{2}$ face. Upon reaction with $\mathrm{CO}$, this complex undergoes cluster degradation to afford a trinuclear phosphinidene complex, $\mathrm{Cp}^{*} \mathrm{WRu}_{2}(\mathrm{CO})_{8}(\mu-\mathrm{H})\left(\mu_{3}-\mathrm{PPh}\right)(\mathbf{I X b})$ in $72 \%$ yield. The related trinuclear $\mathrm{Cp}$ derivative IXa was prepared directly from the combination of $\mathrm{Ru}_{3}(\mathrm{CO})_{10}(\mu-\mathrm{H})\left(\mu-\mathrm{PPh}_{2}\right)$ with $\mathrm{CpW}(\mathrm{CO})_{3} \mathrm{H}$ (Scheme 4). No tetranuclear intermediate VIIIa was observed for this $\mathrm{Cp}$ derivative. The $\mathrm{X}$-ray analysis indicated that the complexes IXa and IXb differ from each other by varying location of the bridging hydride ligand.

\section{Solution Fluxionality of $\mathbf{I X b}$}

Derivative IXa is isostructural with the related phenylimido clusters II and displays a hydride peak at $\delta-17.96\left(J_{\mathrm{P}-\mathrm{H}}=15.6 \mathrm{~Hz}\right)$ and three Ru-CO signals at $\delta 197.0\left(J_{\mathrm{P}-\mathrm{C}}=43 \mathrm{~Hz}\right), 194.6$ and 188.2 in a ratio $2: 2: 2$. 
In contrast, the ${ }^{1} \mathrm{H}$ NMR spectrum of $\mathbf{I X b}$ at $188 \mathrm{~K}$ exhibits two sets of signals at $-19.05\left(J_{\mathrm{W}-\mathrm{H}}=57.6 \mathrm{~Hz}\right.$ and $\left.J_{\mathrm{P}-\mathrm{H}}=17.6 \mathrm{~Hz}\right)$ and -19.17 $\left(J_{\mathrm{P}-\mathrm{H}}=14.4 \mathrm{~Hz}\right)$ and two ${ }^{31} \mathrm{P}$ NMR signals at $\delta 287.0\left(J_{\mathrm{W}-\mathrm{P}}=195 \mathrm{~Hz}\right)$ and $257.6\left(J_{\mathrm{W}-\mathrm{P}}=183 \mathrm{~Hz}\right)$ in an intensity ratio $1: 2.3$, respectively. Based on these NMR data and the results of X-ray analyses, we propose that the dynamic behavior of $\mathbf{I X b}$ is due to rapid and reversible hydride movement from the $\mathrm{Ru}-\mathrm{Ru}$ edge to the adjacent $\mathrm{W}-\mathrm{Ru}$ edge. Such hydride migration is not a remarkable process because there are many precedents for the transition metal hydride complexes [20]. However, the most unusual feature is the observation of site preference of the bridging hydride. We attribute this to the enhanced electron-donating ability of the $\mathrm{Cp}^{*}$ ligand which causes an enhancement of negative charge on the tungsten atom; this charge in turn attracts the positive hydride ligand. A similar explanation has been invoked to account for the conformational preference of the $\mathrm{LM}(\mathrm{CO})_{2}$ center, $\mathrm{M}=\mathrm{W}$ and $\mathrm{Mo}$, and the formation of semi-bridging $\mathrm{CO}$ ligands in the $\mathrm{MCO}_{2}$ alkylidyne clusters [21]. In the tetranuclear clusters $\mathrm{LWOs}_{3}(\mathrm{CO})_{12}(\mu-\mathrm{H})$ and $\mathrm{LWO}_{3}(\mathrm{CO})_{11}(\mu-\mathrm{H})_{3}$, we also noted that the hydrides have a greater tendency to connect to the $\mathrm{W}$ atom [22] as the auxillary ligand being altered from $\mathrm{Cp}$ to the electron-donating $\mathrm{Cp}$ * ligand.

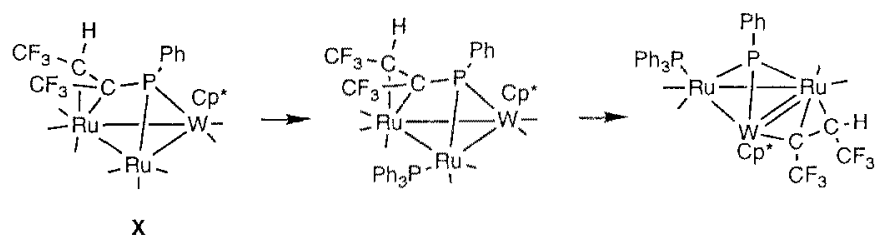

Scheme 5

\section{Reactions of IXb with Hexafluoro-2-butyne}

From the study of structure and solution dynamics of phosphinidene clusters we noticed the existence of some discrepancy between the phenylimido and phosphinidene clusters. In order to compare further their reactivity, we carried out the reactions of phosphinidene clusters IX with hexafluoro-2-butyne. Our result indicates that the alkyne not only reacts with hydride to afford an alkenyl fragment, but the resulting alkenyl fragment further couples with phosphinidene ligand to afford vinyl-phosphido cluster compound $\mathrm{Cp}^{*} \mathrm{WRu}_{2}(\mathrm{CO})_{8}\left(\left[\mu-\mathrm{P}(\mathrm{Ph}) \mathrm{C}\left(\mathrm{CF}_{3}\right) \mathrm{CH}\left(\mathrm{CF}_{3}\right)\right] \quad(\mathbf{X})\right.$ (Scheme 5). This pattern is compatible with other phosphinidene clusters since the tetraruthenium phosphidene cluster $\mathrm{Ru}_{4}(\mathrm{CO})_{13}\left(\mu_{3}-\mathrm{PPh}\right)$ is known to react with alkyne via the formation of $\mathrm{P}-\mathrm{C}$ bond, affording a 
nido-cluster skeleton [23]. Some chemistry of $\mathbf{X}$ has been developed: thermolysis in toluene solution under nitrogen fails to produce a stable complex via $\mathrm{CO}$ elimination. However, while complex $\mathbf{X}$ was treated with triphenylphosphine we obtained a substitution product via simple replacement of a $\mathrm{Ru}$ bound $\mathrm{CO}$ ligand (Scheme 5). Heating of this phosphine derivative in toluene eliminated two $\mathrm{CO}$ molecules and induced the $\mathrm{P}-\mathrm{C}$ bond cleavage to regenerate the $\mu_{3}$-phosphinidene ligand and the $\mathrm{W}=\mathrm{Ru}$ double bond. Apparently, the good $\sigma$-donating and poor $\pi$-accepting property of the triphenylphosphine ligand has a dramatic impact on the stability and reactivity of $\mathbf{X}$.

\section{SUPPLEMENTARY MATERIAL AVAILABLE}

A complete listing of thermal parameters, tables of nonessential bond distances and angles, hydrogen atom coordinates, and listings of the observed and calculated structural factors for complex IV are available from one author (Y.C.).

\section{ACKNOWLEDGMENT}

This research was supported by the National Science Council of the Republic of China (Grant No. NSC 82-0208-M007-079).

\section{REFERENCES}

1. (a) J.-S. Song, G. L. Geoffroy, and A. L. Rheingold (1992). Inorg. Chem. 31, 1505; (b) D. L. Ramage, G. L. Geoffroy, A. L. Rheingold, and B. S. Haggerty (1992), Organometallics 11, 1242; (c) J.-S. Song, S.-H. Han, S. T. Nguyen, and G. L. Geoffroy (1990). Organometallics 9, 2386; (d) Y. Chi, D.-K. Hwang, S.-F. Chen, and L.-K. Liu (1989). J. Chem. Soc, Chem. Commtm. 1540; (e) A. Basu, S. Bhaduri, H. Khwaja, P. G. Jones, K. Meyer-Bäse, and G. M. Sheldrick (1986). J. Chem. Soc., Dalton Trans. 2501; (f) G. D. Williams, G. L. Geoffroy, R. R. Whittle, and A. L. Rheingold (1985). J. Am. Chem. Soc. 107, 729; (g) K. Burgess, B. F. G. Johnson, J. Lewis, and P. R. Raithby (1982). J. Organomet. Chem. 224, $\mathrm{C} 40$.

2. (a) G. Huttner and K. Evertz (1986). Acc. Chem. Res. 19, 406; (b) G. Huttner and K. Knoll (1987). Angew. Chem. Int. Ed. Engl. 26, 743; (c) C. J. Adams, M. I. Bruce, B. W. Skelton, and A. H. White (1991). J. Organomet. Chem. 420, 95; (d) A. J. Deeming, S. Doherty, M. W. Day, K. I. Hardcastle, and H. Minassian (1991). J. Chem. Soc., Dalton Trans. 1273; (e) F. V. Gastel, N. J. Taylor, and A. J. Carty (1987). J. Chem. Soc., Chem. Commun. 1049; (f) R. Khattar, S. Naylor, and M. D. Vargas (1990). Organometallics 9 , 645.

3. Y. Chi, L.-K. Liu, G. Huttner, and L. Zsolnai (1990). J. Organomet. Chem. 390, C50.

4. R.-C. Lin, Y. Chi, S.-M. Peng, and G.-H. Lee (1992). Inorg. Chem. 32, 3818.

5. J. A. Smieja and W. L. Gladfelter (1986). Inorg. Chem. 25, 2667.

6. H. Vahrenkamp (1983). Adv. Organomet. Chem. 22, 169. 
7. S.-H. Han, J.-S. Song, P. D. Macklin, S. T. Nguyen, G. L. Geoffroy, and A. L. Rheingold (1989). Organometallies 8. 2127.

8. Y. Chi, H.-F. Hsu, L.-K. Liu, S.-M. Peng, and G.-H. Lee (1992). Organometallics 11, 1763.

9. (a) S. Bahaduri, K. S. Gopalkrishnan, G. M. Sheldrick, W. Clegg, and D. Stalke (1983). J. Chem. Soc, Dalton Trans. 2339; (b) M. Pizzotti, F. Porta, S. Cenini, and F. Demartin (1988). J. Organomet. Chem. 356, 105; (c) S. Bahaduri, K. S. Gopalkrishnan, W. Clegg, P. G. Jones, G. M. Sheldrick, and D. Stalke (1984). J. Chem. Soc., Dalton Trans. 1675.

10. (a) J. A. Iggo, M. J. Mays, P. R. Raithby, and K. Henrick (1983). J. Chem. Soc, Dalton Trans. 205; (b) J. Ros, J. M. Vinas, R. Mathieu, X. Solans, and M. Font-Bardia (1988). J. Chem. Soc., Dalton Trans. 281; (c) I. Moldes, J. Ros, R. Yanez, R. Mathieu, X. Solans, and M. Font-Bardia (1990). J. Organomet. Chem. 395, 305; (d) S.-H. Chung, Y. Chi, F.-L. Liao, S.-L. Wang, S.-H. Peng, G.-H. Lee, J.-C, Wu, and K.-M. Horng (1991). J. Organomet. Chem. 410, 85.

11. (a) E. Sappa, A. Tiripicchio, and A. M. M. Lanfredi (1983). J. Organomet. Chem. 249, 391; (b) J. J. Guy, B. E. Reichert, and G. M. Sheldrich (1976). Acta Cryst. B 32, 3319; (c) E. Boyar, A. J. Deeming, K. Henrick, M. MacPartlin, and A. Scott (1986), J. Chem. Soc., Dalton Trans. 1431; (d) Y. Chi, B.-F. Chen, S.-L. Wang, R.-K. Chiang, and L.-S. Hwang (1989). J. Organomet. Chem. 377, C59.

12. E. Sappa, A. Tiripicchio, and P. Braunstein (1983). Chem. Rev. 83, 203.

13. (a) A. D. Clauss, M. Tachikawa, J. R. Shapley, and C. G. Pierpoint (1981). Inorg. Chem. 20, 1528; (b) J. R. Shapley, S. I. Richter, M. Tachikawa, and J. B. Keister (1975). J. Organomet. Chem. 94, C43.

14. F. G. Bordwell and M. J. Bausch (1983). J. Am. Chem. Soc. 105, 6188.

15. (a) K. J. Edwards, J. S. Field, R. J. Haines, and F. Mulla (1991). J. Organomet. Chem. 402, 113; (b) K. Natarajan, L. Zsolnai, and G. Guttner (1981). J. Organomet. Chem. 220, 365.

16. (a) A. M. Arif, T. A. Bright, D. E. Heaton, R. A. Jones, and C. M. Nunn (1990). Polyhedron 9, 1573; (b) A. J. Deeming, N. I. Powell, A. J. Arce, Y. De Sanctis, and J. Manzur (1991). J. Chem. Soc., Dalton Trans. 3381.

17. M. Lanfranchi, A. Tiripicchio, E. Sappa, and A. J. Carty (1986). J. Chem. Soc., Dalton Trans. 2737.

18. (a) S. B. Colbran, B. F. G. Johnson, J. Lewis, and R. M. Sorrell (1985). J. Organomet. Chem. 296, C1; (b) S. B. Colbran, B. F. G. Johnson, J. Lewis, and R. M. Sorrell (1986). J. Chem. Soc., Chem. Commun. 525.

19. S. A. MacLaughlin, A. J. Carty, and N. J. Taylor (1982). Can. J. Chem. 60, 87.

20. (a) B. F. G. Johnson and J. Lewis (1981). Adv. Inorg. Chem. Radiochem. 24, 225; (b) E. Band and E. L. Muetterties (1978). Chem. Rev. 78, 639.

21. K. A. Sutin, L. Li, C. S. Frampton, B. G. Sayer, and M. J. McGlinchey (1991). Organometallics 10, 2362.

22. (a) Y. Chi, C.-Y. Cheng, and S. L. Wang (1989). J. Organomet. Chem. 378, 45; (b) S.-M. Peng, G.-H. Lee, Y. Chi, C.-L. Peng, and L.-S. Hwang (1989). J. Organomet. Chem. 371, 197.

23. (a) F. Van Gastel, A. J. Carty, M. A. Pellinghelli, A. Tiripicchio, and E. Sappa (1990). J. Organomet. Chem. 385, C50; (b) J. Lunniss, S. A. MacLaughlin, N. J. Taylor, A. J. Carty, and E. Sappa (1985). Organometallics 4, 2066. 